Original Research

\title{
Perceived Benefits and Intakes of Protein, Vitamin C and Iron in Preventing Anemia among Pregnant Women
}

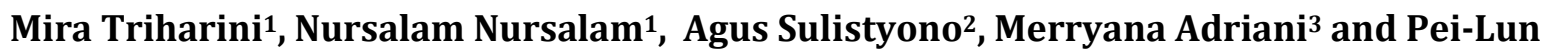 \\ Hsieh $^{4}$
}

${ }^{1}$ Nursing Faculty, Universitas Airlangga, Surabaya, Indonesia

2 Dr. Soetomo General Hospital Surabaya, Indonesia

3 Public Health Faculty, Universitas Airlangga, Surabaya, Indonesia

${ }^{4}$ Chung Hwa University of Medical Technology, Taiwan

\begin{abstract}
Introduction: Nutritional adequacy is essential in ensuring the normal growth and development the fetus. Perceived benefits will be able to strengthen pregnant women to meet optimum nutritional intake to prevent anemia. Adequacy of protein, vitamin $\mathrm{C}$ and iron will reduce the risk of iron deficiency anemia in pregnancy. This study aims to examine the association between perceived benefits with protein, vitamin $\mathrm{C}$, and iron intake in preventing pregnancy anemia.
\end{abstract}

Methods: This study used a cross sectional design and was conducted in AugustOctober 2017 among 105 pregnant women. This study used the multistage random sampling method. The population of this study were pregnant women who had antenatal care in four Community Health Centre in Surabaya namely Jagir, Medokan Ayu, Sidotopo Wetan, and Gundih.

Results: The average daily protein intake was $76.34($ SD = 35.88) gram / day. There was a significant association between perceived benefits with protein intake $(\mathrm{r}=$ $0.272 ; \mathrm{p}=0.005$ ). The average daily vitamin $\mathrm{C}$ intake was 90.67 (SD = 116.54) $\mathrm{mg} /$ day. There was no significant association between perceived benefits and vitamin $C$ intake $(r=0.175 ; p=0.074)$. The average daily iron intake was $64.73(S D=23.13)$ $\mathrm{mg} /$ day. There was a significant association between perceived benefits and iron intake $(r=0.219 ; p=0.025)$.

Conclusion: The knowledge of pregnant women about the benefits of nutrition will affect the adequacy of pregnancy nutrition. Health workers need to provide health education on the importance of nutrition for pregnant women to prevent anemia during pregnancy.

\section{ARTICLE HISTORY}

Received: Feb 21, 2018

Accepted: Nov 28, 2018

\section{KEYWORDS}

anemia during pregnancy; iron deficiency; perceived benefits; protein;

vitamin C

\section{CONTACT}

Mira Triharini

$\triangle$ mira-t@fkp.unair.ac.id

$\doteq$ Nursing Faculty, Universitas Airlangga, Surabaya, Indonesia

Cite this as: Triharini, M., Nursalam, N., Sulistyono, A., Adriani, M., \& Hsieh, P,L. (2018). Perceived Benefits and Intakes of Protein, Vitamin C and Iron in Preventing Anemia among Pregnant Women. Jurnal Ners, 13(2), 156-161. doi:http://dx.doi.org/10.20473/in.v13i2.7712

\section{INTRODUCTION}

Nutritional adequacy during pregnancy will affect the condition of the fetus. The incidence of malnutrition in pregnant mothers will lead to fetal development disorders, preterm labor, infant growth disorders, and the risk of development of chronic diseases (Metgud, Naik, \& Mallapur, 2012). Preeclampsia and gestational diabetes are also associated with poor nutrition (Acharya et al., 2016; Ahmed \& Tseng, 2013). Iron deficiency anemia remains a common problem in pregnancy. A study in the obstetric department of the First Affiliated Hospital of Guangxi Medical University showed that there were more than $70 \%$ of pregnant mothers having iron deficiency anemia. That study result showed the incidence of preterm deliveries and low birth weight babies were significantly more in mothers who were anemic in the third trimesters of pregnancy (Huang, Purvarshi, Wang, Zhong, \& Tang, 2015).

Several studies have shown factors related to the incidence of maternal anemia (Mekuria, Bekele, Tilahun, \& Bekele, 2016; P. Singh, Khan, \& Mittal, 2013).Study in Nepal found as many as $41.02 \%$ of pregnant mothers had anemia and the prevalence was higher in the second trimester of pregnancy and at the age of 20-35 years(P. Singh et al., 2013). A 
research in Southern Ethiopia showed labor spacing of less than two years, iron supplementation, and the number of family members which is more than members two affected the incidence of anemia (Mekuria et al., 2016). Several studies supported the relationship between nutrition and hemoglobin levels (Bahar, 2011; M. B. Singh, Fotedar, \& Lakshminarayana, 2009; Thomson et al., 2011).A research in Indonesia showed that maternal education level, nutritional status, and the intake of iron supplement, vitamin C were significantly associated with pregnancy anemia (Bahar, 2011). Research in Indian Western Rajasthan shows the majority of pregnant women have anemia showed a lack of protein and iron (M. B. Singh et al., 2009).

Nutritional problems in pregnant mothers can be caused by the presence of micronutrient interactions. Interactions between micronutrients will affect the absorption and bioavailability, such as the negative effects of calcium on iron absorption, while on the other hand vitamin $\mathrm{C}$ will increase the absorption of iron. An understanding of the interactions between micronutrients in nutrient intake is necessary as it will help to reduce the risk of micronutrient deficiency, improve micronutrient status, and reduce the risk of deficiency (Sandström, 2001).

The adequacy of nutritional needs in pregnant mothers will be met if they understand about the importance of nutrition in pregnancy. Knowledge of nutrition in pregnant mother sis influenced by several factors. A study at Gote Geda Woreda, East Wollega Zone, Ethiopia showed that the information on nutrition had a significant relationship with the knowledge of pregnant mothers about nutrition .That study showed women who had information about nutrition were 3.6 times more likely knowledgeable about nutrition as compared to the pregnant women with no information about nutrition during pregnancy (AOR=3.59) (Fekadu Beyene, 2013).The adequacy of protein, vitamin C, and iron in the daily diet of pregnant mothers needs to be considered because it has a role to prevent anemia (Abdelwahid, 2013; Brown \& Shapiro, 1996; Rivera-rodriguez, Rodríguez-rivera, Roman-julia, \& Raul, 2016; Sriramanakoppa, Sreenivas, \& Jayaram, 2015). Pregnant mothers need to be givena health education about foods that contain of protein, vitamin C, and iron during antenatal care.Midwivesplayan important role to improve the understanding ofpregnant mothers (Arrish, Yeatman, \& Williamson, 2017).

Health education for pregnant mothers which focus on the perceived benefits about healthy nutrition will improve the nutritional behavior (Khodaveisi, Omidi, Farokhi, \& Soltanian, 2017). Currently there are not many studies that see the association between perceived benefits and nutritional intake to prevent anemia. This study aimed to examine the association between perceived benefits and the intake of protein, vitamin $\mathrm{C}$, and iron in preventing pregnancy anemia.

\section{MATERIALS AND METHODS}

The population of this study were pregnant mothers who examined the pregnancy in four Community Health Center in Surabaya namely Jagir, Medokan Ayu, Sidotopo Wetan, and Gundih Surabaya. This study used multistage random sampling. This study used a cross sectional design which was conducted in August-October 2017 among105 pregnant mothers. The inclusion criteria were pregnant mothers and those who had obtained iron tablet from Community Health Center. The exclusion criteria were pregnant mothers who had complications that required medical treatment. The data collected in this research included perceived benefits and the intake of protein, vitamin $C$, and iron. The demographic characteristics questionnaire consists of several questions that include age, parity, education level, income, and gestational age.

The questionnaires of perceived benefits were developed by researchers with items based on the theory of prevention of maternal anemia and the Pender health-promotion model (HPM) (Pender, 2011; Sharma \& Shankar, 2010). Whilst preparing the questionnaire contents, the researchers were assisted by two experienced nurses in the field of maternity nursing. Translation was accomplished by a qualified translator from Indonesia. Perceived benefits were measured using a questionnaire based on Health Promotion Model theory and anemia theory (Sharma \& Shankar 2010; Pender 2011). Before use in data collection, the compiled questionnaires were tested for validity and reliability on 15 pregnant women who attended antenatal care at the Community Health Centre of Keputih Surabaya. The questionnaire consists of six questions. The Cronbach's $\alpha$ was 0.911 . The six questions featured a Likert scale with the following option strongly agree, slightly agree, hesitate, slightly disagree, strongly disagree.

Measurement of the intake of protein, vitamin $\mathrm{C}$, and iron was done by $1 \times 24$ hours of food recall method in which the result was expressed in grams and mg (Supariasa, Bakri, \& Fajar, 2002). Sample recruited was conducted after obtaining ethical approval from health research ethics committee of Faculty of Public Health Airlangga University Surabaya Indonesia (No 123-KEPK). Informed consent was obtained after pregnant mothers agree to participate in this research. Data analysis using spearman's rho was used to determine the association between the perceived benefits and the intake of protein, vitamin $\mathrm{C}$ and iron. Descriptive statistics used frequency, percentage, mean and standard deviation to identify demographic characteristics, perceived benefits, and nutritional intake. The level of significance used alpha 0.05. The $\mathrm{p}$ value $<0.05$ indicated a significance. All data were analyzed using SPSS software. 


\section{RESULTS}

Table 1 shows the socio demographic characteristics and nutrition intake of protein, vitamin $\mathrm{C}$, and iron. The majority of respondents $(n=73,68 \%)$ were 25 35 years old. Most of respondents ( $\mathrm{n}=73,69.5 \%)$ had parity $1-3$. Most of respondents $(n=81,77.1 \%)$ had secondary education. The majority of respondents $(n=72,68.6 \%)$ had an income below 3 million rupiah per month. Most of the respondents $(\mathrm{n}=88,83.8 \%)$ had gestational age below 37 weeks.

The greatest protein intake was in age 25-35 years (79.82 \pm 38.09), parity was $>3(93.90 \pm$ 125.31), elementary education (79.04 \pm 61.54), income was $\geq 3$ million rupiah $(80.56 \pm 44.76)$, and gestational age was $\geq 37$ weeks $81.02 \pm 36.36$ ). The greatest vitamin $\mathrm{C}$ intake was in age $>35$ years $(102.15 \pm 130.03)$, parity was $>3(209.70 \pm 176.35)$, university education $(116.58 \pm 156.27)$, income was $\geq 3$ million rupiah $(101.42 \pm 139.76)$ and gestational age was $\geq 37$ weeks $81.02 \pm 186.05$ ). The greatest iron intake was in age $>35$ years $(66.11 \pm 15.87)$, nullipara (322.3 \pm 112.8$)$, university education (65.42 \pm 9.67), income was $<3$ million rupiah (65.81 \pm 24.14 ) and gestational age was $\geq 37$ weeks $71.98 \pm$ 10.11).

From five statements about the perceived benefits, the statement of "Consumption of nutritious and high iron will make the baby healthy" has the highest score $(4.48 \pm 0.54)$ and "Regular consumption of iron tablets can prevent infection" has the lowest score $(4.10 \pm 0.74)$ (Table 2).

The average score of perceived benefits was 25.64 (95\% CI 25.08-26.20). The average protein intake of the study population was 76.34 (SD = 35.88 ) g/day. This was equivalent to 99.14 per cent of RDA recommended value for pregnant mothers in this population. There was a significant association between perceived benefits and the protein intake with positive and moderate association $(r=0.272 ; p$

Table 1. Nutrition Intake in Pregnant Mothers ( $\mathrm{N}=105)$

\begin{tabular}{|c|c|c|c|c|c|c|c|}
\hline \multirow{2}{*}{ No } & \multirow{2}{*}{$n(\%)$} & \multicolumn{2}{|c|}{ Protein (gram/day) } & \multicolumn{2}{|c|}{ Vitamin C (mg/day) } & \multicolumn{2}{|c|}{ Iron (mg/day) } \\
\hline & & Mean & SD & Mean & SD & Mean & SD \\
\hline \multicolumn{8}{|l|}{ Age } \\
\hline$<25$ years & $25(23.8)$ & 67.07 & 30.01 & 67.78 & 78.43 & 63.86 & 26.93 \\
\hline $25-35$ years & $73(69.5)$ & 79.82 & 38.09 & 102.15 & 130.03 & 64.89 & 22.58 \\
\hline$>35$ years & $7(6.7)$ & 73.16 & 27.99 & 52.67 & 49.27 & 66.11 & 15.87 \\
\hline \multicolumn{8}{|l|}{ Parity } \\
\hline 0 & $30(28.6)$ & 73.77 & 35.31 & 106.49 & 119.33 & 65.14 & 26.07 \\
\hline $1-3$ & $73(69.5)$ & 76.92 & 36.56 & 80.91 & 113.38 & 64.64 & 22.01 \\
\hline$>3$ & $2(1.9)$ & 93.90 & 25.31 & 209.70 & 176.35 & 61.95 & 32.46 \\
\hline \multicolumn{8}{|l|}{ Education } \\
\hline Elementary & $14(13.3)$ & 77.49 & 31.76 & 115.25 & 166.31 & 65.26 & 33.86 \\
\hline Secondary & $81(77.1)$ & 75.81 & 32.89 & 83.22 & 100.83 & 64.55 & 22.34 \\
\hline University & $10(9.5)$ & 79.04 & 61.54 & 116.58 & 156.27 & 65.42 & 9.67 \\
\hline \multicolumn{8}{|l|}{ Income (Rupiah) } \\
\hline$<3$ million & $72(68.6)$ & 74.40 & 31.15 & 85.75 & 104.94 & 65.81 & 24.14 \\
\hline$\geq 3$ million & $33(31.4)$ & 80.56 & 44.76 & 101.42 & 139.76 & 62.37 & 20.94 \\
\hline \multicolumn{8}{|l|}{ Gestasional age } \\
\hline$<37$ week & 88 (83.8) & 75.44 & 35.92 & 80.31 & 95.91 & 63.33 & 24.67 \\
\hline$\geq 37$ week & $17(16.2)$ & 81.02 & 36.36 & 144.30 & 186.05 & 71.98 & 10.11 \\
\hline
\end{tabular}

Note: 13.500 rupiahs equal to 1 US \$

Table 2. Items of Perceived Benefits Analysis ( $\mathrm{N}=105)$

\begin{tabular}{llcc}
\hline No & \multicolumn{1}{c}{ Items } & Mean & SD \\
\hline 1 & $\begin{array}{l}\text { Consumption of nutritious foods and highiron will make the } \\
\text { baby healthy } \\
2\end{array} \quad \begin{array}{l}\text { Consumption of nutritious foods and highironwill make } \\
\text { deliveries smooth }\end{array}$ & 4.48 & 0.54 \\
3 & $\begin{array}{l}\text { Regular consumption of iron tablets will make mothers } \\
\text { become not quickly tired }\end{array}$ & 4.29 & 0.63 \\
4 & $\begin{array}{l}\text { Regular consumption of irontabletscan prevent infection } \\
\text { Washing hands before eating is important in preventing } \\
\text { anemia of pregnant mothers }\end{array}$ & 4.24 & 0.69 \\
$6 \quad \begin{array}{l}\text { Using footwear when out of home is necessary for the health } \\
\text { of pregnancy }\end{array}$ & 4.10 & 0.74 \\
\hline
\end{tabular}

Table 3. The Relationship between Perceived Benefits and Nutritional Intake (N=105)

\begin{tabular}{llccccccc}
\hline No & \multicolumn{1}{c}{ Variable } & Mean & SD & RDA value & $\begin{array}{c}\text { \% of RDA } \\
\text { Value }\end{array}$ & Min-Max & r & p-value \\
\hline 1 & Perceived benefits & 25.64 & 2.89 & & & $19-30$ & \\
2 & Protein (gram) & 76.34 & 35.88 & 77 & 99.14 & $76.34-250.9$ & 0.272 & 0.005 \\
3 & Vitamin C (milligram) & 90.67 & 116.54 & 85 & 106.67 & $0.8-629.7$ & 0.175 & 0.074 \\
4 & Iron (milligram) & 64.73 & 23.13 & 126 & 51.37 & $9.6-125.3$ & 0.219 & 0.025 \\
\hline SD - Standard Deviation; RDA: Recommended Dietary Allowance; r $=$ Spearman correlation coefficient; & p< 0.05 &
\end{tabular}

SD - Standard Deviation; RDA: Recommended Dietary Allowance; r = Spearman correlation coefficient; $\mathrm{p}<0.05$ 
$=0.005)$. The average of vitamin $\mathrm{C}$ intake of the study population was $90.67(\mathrm{SD}=116.54) \mathrm{mg} / \mathrm{day}$. This was equivalent to 106.67 per cent of RDA recommended value for pregnant mothers in this population. There was no significant association between perceived benefits and vitamin $\mathrm{C}$ intake $(\mathrm{r}=$ $0.175 ; p=0.074)$. The average of iron intake of the study population was $64.73(\mathrm{SD}=23.13) \mathrm{mg} /$ day. This was equivalent to 51.37 per cent of RDA recommended value for pregnant mothers in this population. There was a significant association between perceived benefits and iron intake with possitive and weak association $(r=0.219 ; \mathrm{p}=0.025)$ (Table 3).

\section{DISCUSSION}

The result of this study found that the statement of "Consumption of nutritious foods and high iron will make the baby healthy" had the highest score, while the statement of "Regular consumption of iron tablets can prevent infection" had the lowest score. The knowledge of pregnant mothers about the prevention of anemia had been obtained by mothers through health education from healthcare providers during antenatal care, as well as from the mass media. Pregnant mothers had understood the benefits of eating nutritious foods but had not fully figured out the benefits of the adherence to iron supplementation. There were still many pregnant mothers who did not adhere to taking iron supplementation although iron supplements have been shown to increase the levels of hemoglobin to prevent the occurrence of anemia (Sajith et al., 2016). Iron supplements need to be taken regularly by every pregnant mother every day during her pregnancy or at least 90 tablets. Daily oral iron supplementation with $60 \mathrm{mg}$ of elemental iron and $0.4 \mathrm{mg}$ folic acid (Health Ministry of health, 2014).

The adequacy of nutrients during pregnancy will contribute greatly to the health of the fetus and the well-being of pregnant mothers. However, the result of the study found that many pregnant mothers having not received adequate nutrition were those who were among the group of underweight or overweight/obese, smokers, adolescents, and those with previous unfavorable pregnancy outcomes (Marangoni et al., 2016). Underweight conditions during pregnancy are associated with poor fetal development, preterm, and an increased risk of chronic disease later in life, while pregnant mothers will be at risk of gestational diabetes and preeclampsia (Ahmed \& Tseng, 2013).

Food recall in this study showed that the intake of protein and vitamin $C$ in this population was in good category but the intake of iron was still in the low category. The adequacy of iron in the diet is influenced by maternal adherence to $\mathrm{Fe}$ supplements. Each iron supplement for pregnant mothers at least containing iron that was equivalent to $60 \mathrm{mg}$ of iron elements (in the form of Ferro Sulfate, Ferro Fumarate or Ferro Gluconate) preparations; and Folic Acid $0.400 \mathrm{mg}$ (Health Ministry of health, 2014).Some studies supported the low iron adequacy in pregnant mothers (Mosha et al., 2017; Sato, Fujimori, Szarfarc, Borges, \& Tsunechiro, 2010). The inadequacy of iron in the diet in this population might be influenced by the respondent's characteristics with the lowest mean intake of iron with more than 3 parities. The majority of respondents in this study had income less than 3 million. The provision of food in the family is closely related to the appetite of other family members and the priority of financial use. A study supported the relationship between socioeconomic and dietary patterns in pregnant mothers. A study showed the mother with higher level of financial resources to buy food, has higher consumption of saltwater fish, fruit, products being the source of animal protein (Suliga, 2013; Völgyi et al., 2013).

The result showed a significant association between the perceived benefits and the intake of protein and iron. Perceived benefits of actions reinforce consequences for certain health behaviors. Perceived benefits can increase individual's commitment in conducting health behavior. Perceived benefit is a concept of Pender Health Promotion Model that supports 6 major components of healthy lifestyle. These components include health responsibility, physical activity, nutrition, spiritual growth, interpersonal support and stress management (Eshah, Bond, \& Sivarajan, 2010).The results of several studies supported that perceived benefits can improve health behavior in various areas (Kim, Ahn, \& No, 2012; Lovell, Ansari, \& Parker, 2010; Noroozi, Esmaili, Tahmasebi, \& Vahdat, 2017; Salahshoori, Sharifirad, Hassanzadeh, \& Mostafavi, 2014). In this study perceived benefits were associated with the prevention behavior of anemia during pregnancy. Pregnant women with good perceived benefits will try to meet the daily nutritional adequacy despite the obstacles experienced.

Pregnant mothers can experience many obstacles in fulfilling daily nutritional needs. A study of iron supplementation showed that the majority of pregnant mothers suffered from gastrointestinal disorders such as nausea, diarrhea and constipation (Tolkien, Stecher, Mander, Pereira, \& Powell, 2015).A study looked at the perception of anemia pregnancy and its prevention in several countries. That study showed Pregnant mothers in Bolivia, Guatemala, and Honduras had realized that the consequences of anemia were serious and anemia can be fatal for both mother and baby. Result that study in Indonesia showed that anemia was equal to the term low blood pressure. Some pregnant mothers stated that consumption of iron supplements would increase blood and was associated with hypertension (Galloway et al., 2002). The difference in perceptions of pregnant women about anemia shows the importance of health education about anemia to 
improve anemia prevention behavior in pregnant women.

\section{CONCLUSION}

The finding from this study has confirm that mother with good perception on benefits will have better intake of protein and iron in pregnant mothers. Health workers need to provide health education to every pregnant woman to increase the perceived benefits of preventing anemia. A good understanding of the importance of prevention of anemia, will improve the behavior of mothers in fulfilling daily nutritional needs, especially protein, vitamin $\mathrm{C}$ and iron.

\section{REFERENCES}

Abdelwahid, H. A. (2013). The Role of Multiple Micronutrients in Treatment of Iron Deficient Anemic Children. Family Medicine \& Medical Science Research, 1(1), 2-5. https://doi.org/10.4172/2327-4972.1000102

Acharya, O., Zotor, F. B., Chaudhary, P., Deepak, K., Amuna, P., \& Ellahi, B. (2016). Maternal Nutritional Status, Food Intake and Pregnancy Weight Gain in Nepal. Journal of Health Management, 18(1), 1-12. https://doi.org/10.1177/0972063415625537

Ahmed, F., \& Tseng, M. (2013). Diet and nutritional status during pregnancy. Public Health Nutrition, 16(8), 1337-1339. https://doi.org/10.1017/S1368980013001651

Arrish, J., Yeatman, H., \& Williamson, M. (2017). Midwives' Role in Providing Nutrition Advice during Pregnancy: Meeting the Challenges? A Qualitative Study. Nursing Research and Practice, 2017, $1-11$. https://doi.org/10.1155/2017/7698510

Bahar, F. V. H. B. (2011). Pola Konsumsi Dan Kadar Hemoglobin Pada Ibu Hamil Di Kabupaten Maros , Sulawesi Selatan. Kesehatan, 15(1), 31-36.

Brown, M. S., \& Shapiro, H. (1996). Effect of protein intake on erythropoiesis during erythropoietin treatment of anemia of prematurity. J Pediatr.

Eshah, N. F., Bond, A. E., \& Sivarajan, E. (2010). The effects of a cardiovascular disease prevention program on knowledge and adoption of a heart healthy lifestyle in Jordanian working adults. European Journal of Cardiovascular Nursing, 9(4), 244-253. https://doi.org/10.1016/j.ejcnurse.2010.02.002

Fekadu Beyene, G. D. (2013). Assessment of Knowledge of Pregnant Mothers on Maternal Nutrition and Associated Factors in Guto Gida Woreda, East Wollega Zone, Ethiopia. Journal of Nutritional Disorders \& Therapy, 04(01), 1-7. https://doi.org/10.4172/2161-0509.1000130

Galloway, R., Dusch, E., Elder, L., Achadi, E., Grajeda, R., Hurtado, E., ... Stephen, C. (2002). Women's perceptions of iron deficiency and anemia prevention and control in eight developing countries. Social Science \& Medicine, 55(4), 529-
544. 9536(01)00185-X

https://doi.org/10.1016/S0277-

Health Ministry of health. (2014). PMK No. 88 Tablet Tambah Darah. Kemenkes 2014, (1), 1-5. https://doi.org/10.1007/s13398-014-0173-7.2

Huang, L., Purvarshi, G., Wang, S., Zhong, L., \& Tang, H. (2015). The Influence of Iron-deficiency Anemia during the Pregnancy on Preterm Birth and Birth Weight in South China. Journal of Food and Nutrition Research, 3(9), 570-574. https://doi.org/10.12691/jfnr-3-9-2

Khodaveisi, M., Omidi, A., Farokhi, S., \& Soltanian, A. R. (2017). The Effect of Pender's Health Promotion Model in Improving the Nutritional Behavior of Overweight and Obese Women. International Journal of Community Based Nursing and Midwifery, 5(2), 165-174. Retrieved from http://www.ncbi.nlm.nih.gov/pubmed/2840917 0\%0Ahttp://www.pubmedcentral.nih.gov/article render.fcgi?artid=PMC5385239

Kim, H.-S., Ahn, J., \& No, J.-K. (2012). Applying the Health Belief Model to college students' health behavior. Nutrition Research and PracticeNutr Res Pract), 6(6), 551-558. https://doi.org/10.4162/nrp.2012.6.6.551

Lovell, G. P., Ansari, W. El, \& Parker, J. K. (2010). Perceived exercise benefits and barriers of nonexercising female university students in the United Kingdom. International Journal of Environmental Research and Public Health, 7(3), 784-798. https://doi.org/10.3390/ijerph7030784

Marangoni, F., Cetin, I., Verduci, E., Canzone, G., Giovannini, M., Scollo, P., ... Poli, A. (2016). Maternal diet and nutrient requirements in pregnancy and breastfeeding. An Italian consensus document. Nutrients, 8(10), 1-17. https://doi.org/10.3390/nu8100629

Mekuria, A., Bekele, A., Tilahun, M., \& Bekele, A. (2016). Prevalence of anemia and its associated factors among pregnant women attending antenatal care in health institutions of Arbaminch town , Gamo Gofa Zone, Ethiopia: a crosssectional study. Hindawi Publishing Corporation, 2016(2016),

10. https://doi.org/10.1155/2016/1073192

Metgud, C. ., Naik, V. ., \& Mallapur, M. . (2012). Effect of maternal nutrition on birth weight of newborn-a community based study. The Journal of Family Welfare, 58(2), 35-39.

Mosha, D., Liu, E., Hertzmark, E., Chan, G., Sudfeld, C., Masanja, H., \& Fawzi, W. (2017). Dietary iron and calcium intakes during pregnancy are associated with lower risk of prematurity, stillbirth and neonatal mortality among women in Tanzania. Public Health Nutrition, 20(4), 678-686. https://doi.org/10.1017/S1368980016002809

Noroozi, A., Esmaili, F., Tahmasebi, R., \& Vahdat, K. (2017). The Effect of Education Based on Health Promotion Model (HPM) on Adherence to Antiretroviral Therapy (ART) in HIV-Infected Patients. Health Scope, (7), 1-10. 
https://doi.org/10.5812/archneurosci.30362.Re view

Pender, N. J. (2011). Heath Promotion Model Manual (pp. 4-6). Chichago: University of Michigan.

Rivera-rodriguez, K. M., Rodríguez-rivera, A. V, Roman-julia, R., \& Raul, H. (2016). Effectiveness of Vitamin $C$ in the Treatment of Anemia in Patients with Chronic Diseases: A Case Study. Pharmacy \& Pharmaceutical Sciences, 5(4), 31-35.

Sajith, M., Nimbargi, V., Shah, S., Tekawade, S., Agiwale, J., \& Pawar, A. (2016). Correlations of adherence to iron supplements and prevalence of anemia in antenatal women. International Journal of Reproduction, Contraception, Obstetrics and Gynecology, 5(10), 3448-3452. https://doi.org/http://dx.doi.org/10.18203/232 0-1770.ijrcog20163421

Salahshoori, A., Sharifirad, G., Hassanzadeh, A., \& Mostafavi, F. (2014). An assessment of the role of perceived benefits, barriers and self-efficacy in predicting dietary behavior in male and female high school students in the city of Izeh, Iran. Journal of Education and Health Promotion. https://doi.org/10.4103/2277-9531.127558

Sandström, B. (2001). Micronutrient interactions: effects on absorption and bioavailability. British Journal of Nutrition, 85(S2), S181. https://doi.org/10.1049/BJN2000312

Sato, A. P. S., Fujimori, E., Szarfarc, S. C., Borges, A. L. V., \& Tsunechiro, M. A. (2010). Food Consumption and Iron Intake of Pregnant and Reproductive Aged Women. Revista Latino-Americana de Enfermagem, 18(2), 247-254. https://doi.org/10.1590/S010411692010000200016

Sharma, J. B., \& Shankar, M. (2010). Anemia in Pregnancy. JIMSA, 23(4), 253-260.

Singh, M. B., Fotedar, R., \& Lakshminarayana, J. (2009). Micronutrient deficiency status among women of desert areas of western Rajasthan, India. Public Health Nutrition, 12(5), 624-629. https://doi.org/10.1017/S1368980008002395

Singh, P., Khan, S., \& Mittal, R. K. (2013). Anemia During Pregnancy in the Women of Western Nepal. Bali Medical JournalBMJ), 2(1), 14-16. Retrieved from www.balimedicaljournal.com\%0Awww.ojs.unud. ac.id

Sriramanakoppa, N., Sreenivas, \& Jayaram, S. (2015). Study of anemia among protein energy malnourished children in Mysore. Journal of Evidence Based Medicine and Healthcare, 2. https://doi.org/10.18410/jebmh/174

Suliga, E. (2013). Economic and social factors and the quality of nutrition of pregnant women. Studia Medyczne, 29(2), 160-166.

Thomson, C. A., Stanaway, J. D., Neuhouser, M. L., Snetselaar, L. G., Stefanick, M. L., Arendell, L., \& Chen, Z. (2011). Nutrient Intake and Anemia Risk in the Women's Health Initiative Observational Study. Journal of the American Dietetic Association, 111(4), 532-541. https://doi.org/10.1016/j.jada.2011.01.017

Tolkien, Z., Stecher, L., Mander, A. P., Pereira, D. I. A., \& Powell, J. J. (2015). Ferrous sulfate supplementation causes significant gastrointestinal side-effects in adults: A systematic review and meta-analysis. PLOS ONE, $10(2)$, $1-20$. https://doi.org/10.1371/journal.pone.0117383

Völgyi, E., Carroll, K. N., Hare, M. E., Ringwald-Smith, K., Piyathilake, C., Yoo, W., \& Tylavsky, F. A. (2013). Dietary patterns in pregnancy and effects on nutrient intake in the mid-south: The conditions affecting neurocognitive development and learning in early childhood (CANDLE) study. Nutrients, 5(5), 1511-1530. https://doi.org/10.3390/nu5051511 